\title{
Effects of Smart Reading in the Elementary English Classroom
}

\author{
Myeonggi Jeong \\ Seoul Song Jeong Elementary School, Seoul, 157-811, Korea \\ Heecheol Jeon \\ Kyeonggi Chodang Elementary School, Yongin, 446-916, Korea \\ Jeongryeol Kim \\ Korea National University of Education, Chungbuk, 363-791, Korea
}

\begin{abstract}
The Purpose of this study is to examine the effects of the Smart reading program, Smartree, in an elementary English class. Recently in Korea, the use of smart technologies in education has become an issue with the introduction of a new educational platform and increased social interaction between teachers and students. The Smart learning paradigm is converging with technology and social learning. This study examines an English reading method using smart technology and how it affects the improvement of elementary students' reading ability, we also suggest effective reading methods related to Smart learning suitable for this new educational trend. The results showed that the use of a tablet PC based Smartree reading program had meaningful effects on both improvements of cognitive reading ability and changes in affective attitude.
\end{abstract}

Keywords: Smart Learning, Smartree Reading Program, Reading Ability, Affective Attitude.

\section{INTRODUCTION}

As an international language, English is at the center of the medium that connects the knowledge and information we have in the 21st century. Its importance increases as time goes on. English is a survival tool for daily information exchanges in the rapidly changing times. Korea has included English as a regular subject in the elementary education curriculum since March 1997 to adapt to this change. After 16 years, the importance of English education is being emphasized again, increasing English lessons by hour per week since 2010.

Due to the 7th English curriculum, its application, and emphasis in the communication centered approach, learners' listening and speaking abilities are regarded as being important. As a result, students' English listening and speaking abilities have improved through various teaching methods. Although the focus has been on speaking, the opportunities to use English are very rare because students learn English as a Foreign Language (EFL) in Korea. Reading can be an effective means of helping children increase their communication ability and help make English more fun and interesting. In his study, [2] concluded that reading enforces interests and willingness of beginner level children. He also reported that reading increased basic character understanding

* Corresponding author,Email:jmgedic@naver.com Manuscript received Jan. 09, 2014; revised Apr. 01, 2014; accepted Apr. 08, 2014 as well as contributing to the improvement of vocabulary learning in other languages, showing the importance and effectiveness of English reading.

However, when we look at the elementary school English textbook, it only includes postcards and short texts of less than a paragraph. In addition, the importance of reading in English increases as students move onto junior high and high school. Language learners want to read the target language fluently. Therefore, texts should not be ignored in elementary schools. In addition, the ultimate purpose of teaching English reading is to increase English input which is definitely needed in the foreign language learning environment like Korea [3].

Lessons using multimedia materials can influence the effective learning of reading. Using multimedia can also complement teaching. In particular, multimedia can create a real teaching/learning environment through actual situations using videos and stereophonic sounds and by supplying a native speaker's pronunciation. Students' concentration can be increased by inducing their interests. English teaching using multimedia can maximize the learning effect by activating learners' learning process. Teaching/learning English reading by using various characteristics of multimedia helps to increase English reading ability and has positive effects on affective attitude. There have been no precise studies on how an English reading class with technology affects English reading ability and the affective attitude of the learner. 
In considering future learners who adapt to the rapidly changing IT society, it is time to re-establish the education paradigm related to teaching reading from a new angle. It seems that the current text based book-type textbook has limitations in teaching English reading. Teaching English reading through mlearning using tablet PC, etc. can supply integrated materials between languages with its hypertext and hypermedia functions that cannot be achieved through printed materials. It is advantageous in that it can teach integrating language functions using non-simultaneity of text or voice notice boards and simultaneity of chatting voice notice board as the computer communication medium.

Thus, this research focuses on English reading using tablet PC discussing the improvement of elementary students' reading ability and changes of affective attitude, and suggests effective reading methods related to Smart learning suitable for the new educational trend.

\section{BACKGROUNDS}

\subsection{Evolution of Smart Learning}

For some time, IT has been regarded as a solution to improve the quality of education. In this sense, the use of advanced technologies in the educational field has increased significantly and promoted a paradigm shift in the educational environment during the last decade. Many countries expect that IT can enhance the quality of education and can expand the education industry. Therefore, the utilization and implementation of advanced technology that prompting a new learning environment is very important to the government. That is why the Korean government has chosen 'e-Learning' as a top priority for the next few years.

ICT and the educational environment has changed significantly and the rate in which ICT is being implemented in the in education field has increased rapidly. For example, there is a big paradigm shift from e-Learning which was defined as computer-based training to m-Learning which is driven with advancement in mobile and wireless technologies. M-learning has improved a lot compared to e-Learning in terms of flexibility of place, cost, ease of use and timely application. MLearning is very similar to e-Learning, but the only difference is using mobile devices and wireless technology. The development of ICT has caused changes in the educational environment again from the m-Learning environment to the $\mathrm{u}-$ Learning environment. The u-Learning environment is an educational environment which allows students to study anytime and anywhere through diverse terminals without limitations of time, place or environment [1]. Recent interest in education is social learning which uses smart devices and SNS service as educational instruments. In social learning, students can share knowledge through their SNS, and connect with teachers by tagging and sharing multimedia content that they have created. However, the adoption of social technologies in the educational system can cause problems such as privacy issues and copyright of content. Related studies have just begun, and the educational effects of social networking technologies in education have become problematic. Recently in Korea, the
Smart Learning paradigm, a convergence concept of u-learning and social learning, is emerging. The evolution of Smart Learning is expected to improve the educational environment and advance it to the next level. However, discussions on Smart Learning have just become active in Korea, and related studies are insufficient.

\subsection{English Reading}

Language is a means of the manifestation of all humans' thoughts, values, feelings and intentions. As a powerful tool for creating meaning, it can play a basic role of socialization, being unable to be separated from human behaviors. [6] believes language to be a way of describing and representing human experience and understanding the world, wherein members of a language community share systems of beliefs and assumptions which underlie their constructions of the world.

Understandably, the relationship between language and culture is considered significant in language teaching and learning. Accordingly, the current landscape of the EFL/ESL field emphasizes socio-linguistic and cultural factors, seeing language as a social product. With this trend reflected on English reading instruction, the shift to Communicative Language Teaching necessitates new reading methods which focus on the socio-cultural and critical dimensions rather than on linguistic or cognitive ones that were centered on in the past. A brief examination of diverse perspectives on English literacy such as linguistic, cognitive, sociolinguistic, cultural and critical perspectives will offer a better understanding of what is going on in teaching and learning reading (L1/L2) comprehension activities.

Language comprehension is viewed as an active, constructive process that applies to reading. Individuals make use of two types of declarative knowledge to identify the meaning of propositions: real world knowledge and linguistic knowledge [5]. Complex processing and strategic analysis aid the individual in detecting or inferring meanings and in relating information to existing knowledge. The various ways in which existing knowledge is stored, whether as real world knowledge or linguistic knowledge, will be taken advantage of to assist in interpreting the text's meaning. Readers who make use of real world schematic knowledge to develop expectations of text meaning are using top-down processing [4]. Individuals who analyze each individual word for its meanings or grammatical characteristics and then accumulate meanings to form propositions are using bottom-up processing [4].

\subsection{Smart Learning in Korea}

So far there is no clear definition of Smart learning. Scholars are saying that Smart learning should not be limited to just utilizingsmart devices. Thus, the government, academia and educational industry have been working on defining Smart Learning. The Smart Learning Korea forum (2010), proposed the following in understanding Smart Learning: First, its focus is on people and content rather than on the device; second, it is effective intelligent tailored-learning based on an advanced ICT infrastructure. 
What does Smart learning in Korea mean? MEST(The Korean Ministry of Education, Science and Technology) defined Smart Learning as Self-directed, Motivated, Adaptive, Resource enriched, and Technology embedded. S.M.A.R.T Learning promoted by MEST is defined as follows:

S: Self-Directed-the educational system is shifting towards a self-learning system. Students' roles are changing from that of knowledge adopter to knowledge creator. Also, the teacher is a facilitator of learning rather than just teaching.

M: Motivated-education is experience centered--that is, learning by doing. It pursues creative problem solving, and individualized assessment.

A: Adaptive-the education system's flexibility and realization of tailored-learning for individual preference and future careers.

$\mathrm{R}$ : Resource free-Smart Learning utilizes rich contents, based on an open market and cloud education service from both the public and private sector. In other words, it expands the scope of learning resources including collective intelligence (Social Learning).

T: Technology embedded-students can learn anywhere, any time through advance technologies. Fig. 1 shows a holistic concept of SMART education in Korea.

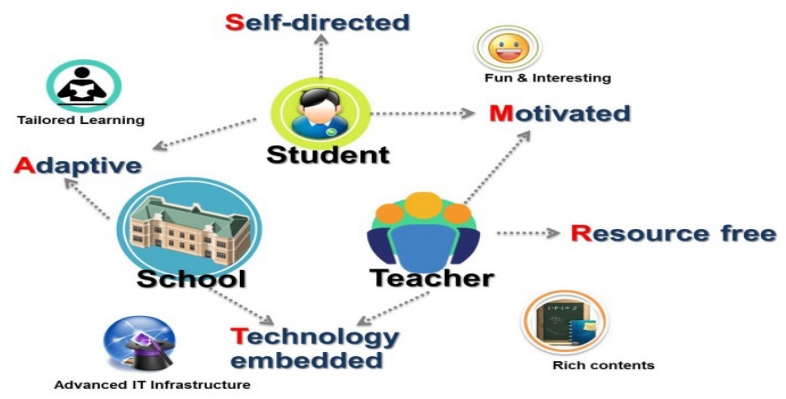

Fig. 1. Smart Education in Korea

The Korean government has been making efforts to establish an educational environment with advanced information technology, such as e-Learning, and u-Learning in public education. Korea has an excellent information and communications infrastructure essential to the digitalized educational environment. High-speed Internet has been installed nationwide, and there are a number of leading electronics companies like Samsung and LG in Korea engaged in smart device and telecommunication technologies.

Recently, the use of smart devices as smartphones and smart pads has rapidly increased causing a new paradigm shift in Smart Learning. This cutting edge technology regarding broadband internet and devices has had a profound impact on the educational industry and related policies. These are the reasons why the Korean government has recognized the eLearning education program as the future growth engine for the last few years. The recent master plan of the government has been focused on the evolution of Smart Learning environments and to secure educational services with social technologies. The Korean Government has introduced e-Learning early on and $\mathrm{u}-$ learning in public education and has made a massive investment in the field, in order to solve the educational problems and to respond to new paradigm shift in education.

\subsection{Smartree Reading Program}

Smartree reading program of domestic K company composes five steps. The first step is called 'Spark' which stimulates curiosity by fun-oriented learning and includes phonics, basic letters, and words. The second step is 'Motivate' which includes reading skill creativity by reading fluency and controlled speaking and writing drills. The third step is 'Activate' which includes reading skill and critical thinking skill by reading. This step also has guided speaking and writing practice. The fourth step is 'Re-create' which includes notetaking and collecting skills. In this step, learners practice summary after reading and presentation. The last step is 'Transform' which includes presentation skill by reading and note-taking. Also this step encourages essay improvement by writing process.

\section{METHODS}

\subsection{Participants}

This study was conducted with 6th grade students in C elementary school located in Kyeonggi, Y city. Students participating in this study were advanced level according to the periodical national examination. The experimental group $(\mathrm{N}=$ 30) used the Smartree reading program for Tablet PCs. Unlike the traditional English reading textbook, this program enables students to receive systematic reading education in five steps by using various multimedia elements.

The comparison group was composed of students who used e-textbooks converted into pdf files from the Smartree reading program. Students in the comparison group $(\mathrm{N}=30)$ used an e-textbook on a personal computer in a computer lab. Finally, the control group $(\mathrm{N}=30)$ consisted of students who had reading lessons with printed material. This study examined the homogeneity test based on reading ability results developed by the researcher.

The size of each group was 30 to ensure validity of the results of the study, and the participants took a pilot test and a survey from October to November in which they self-evaluated their English reading learning through reading materials using smart devices. They also took a preliminary survey before the study started. Referring to the previous study of Bush (2011), in the preliminary survey, participants described their experience with smart devices, frequency of use, and pros and cons of reading materials on smart devices.

\subsection{Materials}

3.2.1 Reading ability test: Reading ability tests were conducted prior and following reading lessons using digital materials to evaluate reading ability, examining vocabulary comprehension, ability to read passages, and application ability. There were various measures for reading ability such as percentile, raw scores, rating, etc, but raw scores were used for convenience in the study. The test paper utilized the reading scripts extracted from 7 textbooks currently used in classrooms. This test paper was comprised of 10 bottom-up processing 
questions and 10 top-down processing questions. The bottomup processing questions were divided into two sub- questions, 5 finding words and expressions questions and 5 questions given after reading some passages. It included understanding precise contents of given passages or determining the match. Meanwhile, top-down processing questions consisted of finding the topic or subject, atmosphere, purpose, or logical reasoning, after reading the passages.

The reading competency test was also conducted with randomly chosen 6th grade elementary students, all of whom did not participate in the study for examining homogeneity in pre-post difficulty. As a result, even though the mean scores of the pre and post-tests differed slightly, it was revealed that the pre- and post- tests showed no significant difference.

3.2.2 Affective attitude survey: The affective attitude survey for this study consisted of three parts. Both pre- and postsurveys included individual questions about the change of learners' attitude and motivation in English learning, the change of learners' thoughts and attitude related to English class, and the change of learners' reading learning style.

3.2.3 Satisfaction survey: The satisfaction survey used a 5 point scale (1point: never $\sim 5$ point: very much) and consisted of 20 questions to examine satisfaction on reading activities in Smartree program. The higher the scores were, the higher the satisfaction was. The survey consisted of questions regarding the satisfaction of the Smartree reading program, convenience in use, and satisfaction of subject contents. This survey guaranteed validity such as system satisfaction $(\alpha=.935)$, and education satisfaction $(\alpha=.974)$.

3.2.4 Teachers' Note \& Learners' Diary: The experiment applying the Smartree program was conducted 8 times during the experimental period with 8 lesson plans. The teacher's notes about lessons using the Smartree program were written after each lesson was finished. The teacher's notes included preparation for class, what to teach, how to teach, responses from students, and feedback for future lessons. Meanwhile, the learners wrote in diaries after each lesson to record their opinions and attitudes on the lessons using the Smartree program. In total, 8 diary entries from each learner were collected. Students'opinions and attitudes diaries were analyzed qualitatively.

\subsection{Procedure}

3.3.1 Design: The purpose of this study is to examine the impact that English reading with smart devices have on English reading ability and effectiveness. The experiment with three groups was conducted as found in Table 1 .

Table 1. Experimental Design

\begin{tabular}{llll} 
G1(controlled) & O1 & & O2 \\
G2(comparison) & O3 & X1 & O4 \\
G3(experimental) & O5 & X2 & O6 \\
\hline
\end{tabular}

G1: English reading with textbook group
G2: e-textbook transformed into pdf file group

G3: Smartree program for Tablet PC group

$\mathrm{X} 1$ : e-textbook for pdf file group

X2: Smartree program for Tablet PC group

Each group consisted of 30 participants, and had a reading class for 8 periods ( 4 weeks). After this, the study examined the effectiveness of the smart device by measuring the changes in English reading ability and affective attitude.

3.3.2 Lesson: Lessons were conducted with the Smartree reading program of domestic company $\mathrm{K}$ for 8 periods (4 weeks). Three groups had their own experimental ways, and did additional activities according to their own ways. The contents of this program are as follows. See Table 2.

Table 2. Contents of Smartree Program

\begin{tabular}{|c|c|}
\hline $\begin{array}{l}\text { Transform } \\
\text { (Transform } \\
\text { into new) }\end{array}$ & $\begin{array}{l}\text { Reading Skill \& Critical Thinking Skill } \\
\text { Presentation by Research \& Note-taking } \\
\text { Essay Improvement by Writing Process }\end{array}$ \\
\hline $\begin{array}{l}\text { Re-create } \\
\text { (Recreate } \\
\text { what we've } \\
\text { learned) }\end{array}$ & $\begin{array}{l}\text { Reading Skill \& Critical Thinking Skill } \\
\text { Note-taking, Collecting } \\
\text { Paragraph by Reading, Listening, \& Grammar } \\
\text { Summary after reading, Presentation }\end{array}$ \\
\hline $\begin{array}{l}\text { Activate } \\
\text { (Activate the } \\
\text { contents) }\end{array}$ & $\begin{array}{l}\text { Guided Speaking \& Writing Practice } \\
\text { Accuracy Improvement by Grammar } \\
\text { Reading Fluency by Speed Reading Practice }\end{array}$ \\
\hline $\begin{array}{l}\text { Motivate } \\
\text { (Self- } \\
\text { motivating) }\end{array}$ & $\begin{array}{l}\text { Reading Skill Creativity by Reading Fluency } \\
\text {-> Output through Speaking \& Writing } \\
\text { Controlled speaking \& writing drills }\end{array}$ \\
\hline $\begin{array}{l}\text { Spark } \\
\text { (Spark } \\
\text { learners) }\end{array}$ & $\begin{array}{l}\text { Stimulate curiosity by fun-oriented learning } \\
\text { Phonics \& read and write letters and words }\end{array}$ \\
\hline
\end{tabular}

The contents of this program consist of five steps according to the learners' level. The participants of this study were advanced, so they studied English with the 'Re-create' step. The re-create step includes promoting creativity by reading with skills and strategies, note-taking, paragraph reading, listening and grammar, and summarizing after reading.

The experimental lessons were conducted with pre-, while-, and after reading activities. The pre-reading activities motivated learning by helping learners find the goal and importance of reading texts, and revitalizing schema on learning contents. The while-reading activities included improving creativity by reading texts with skills and strategies, improving reading skills and critical thinking skills by reading, and improving information collection ability by note taking through reading and listening. Finally, after-reading activities were used to evaluate learners' comprehensibility on reading contents and summary of reading texts.

\subsection{Data Collection and Analysis}

The data collected in this research was statistically treated through SPSS 18.0 for Windows. The changes in reading ability and affective attitude pre- and post- Smartree reading 
program-based instruction, and the satisfaction of program and contents were assessed.A paired $t$-test was conducted to assess the changes in reading ability and the scores of the pre- and post- tests were analyzed based on the bottom-up and top-down reading items.A paired $t$-test was also conducted to assess the changes in affective attitude. The scores of the pre- and posttests were analyzed based on personal motivation in English learning, attitude towards English class and reading in English.

The Survey was conducted to assess the learners' satisfaction of the Smartree reading program based instruction (SRPI). A 5-point scale was used to assess the satisfaction of the system and learning. The average of each group was compared. Meanwhile, teacher's notes and learner diaries were analyzed qualitatively. These were categorized into 4 areas: preparation for class, processing class, responses from students, and feedback for future lessons. The learners' diaries were analyzed for learners' opinions and attitude on class materials and processing class.

\section{RESULTS}

\subsection{The Effects of SRPI on Reading Ability}

Significance verification was performed by carrying out pre- and post- reading ability tests. The purpose of the tests was to detect the difference in improvement among controlled (using textbook), comparison (using PDF e-book) and experimental groups (using SRPI). The results are as follows. See Table 3.

Table 3. Results of Reading Ability by Groups

\begin{tabular}{cccccccc}
\hline \hline \multirow{2}{*}{ group } & $\mathrm{N}$ & \multicolumn{2}{c}{ Pre score } & \multicolumn{2}{c}{ Post score } & \multirow{2}{*}{$t$} & $p$ \\
\cline { 3 - 6 } & Mean & $\mathrm{SD}$ & Mean & $\mathrm{SD}$ & & \\
\hline $\begin{array}{c}\text { Con- } \\
\text { trolled }\end{array}$ & 30 & 11.80 & 2.44 & 12.40 & 1.50 & -.66 & .517 \\
\hline $\begin{array}{c}\text { Com- } \\
\text { pared }\end{array}$ & 30 & 12.20 & 2.48 & 12.90 & 1.91 & -.70 & .489 \\
\hline $\begin{array}{c}\text { Experi- } \\
\text { mental }\end{array}$ & 30 & 11.60 & 2.37 & 13.40 & 1.91 & -2.36 & .030 \\
\hline
\end{tabular}

The total score for the reading ability test was 20 . The post- reading ability test score for the controlled group was 12.40 and there was no significant difference. For the comparison group, it was 12.90 . Though it improved .70, it is hard to be considered significant. However, there was significant difference for the experimental group, which improved from 11.60 to 13.90 . There was slight improvement in each of the controlled and comparison groups, but the fact that there was significant change only for the experimental group reveals the Smart reading program based instruction had positive effects on reading ability.

4.1.1 Reading Ability by Test Type: Since there was a significant difference only for the experimental group for overall reading ability, the test types were classified for more detailed analysis. They were divided into 10 bottom-up and 10 top-down questions to analyze learning effects according to reading activity. Bottom-up type questions included sentence completion, filling in the blanks and identifying detailed information while top-down types included finding out the main idea and making logical inference. The results are as follows. See Table 4.

Table 4. Results of Reading Ability by Test Type

\begin{tabular}{|c|c|c|c|c|c|c|c|}
\hline group & type & test & $\mathrm{N}$ & Mean & SD & $t$ & $p$ \\
\hline \multirow{4}{*}{ Con-trolled } & \multirow{2}{*}{$\begin{array}{l}\text { bottom- } \\
\text { up }\end{array}$} & pre & 30 & 6.40 & 1.14 & \multirow{2}{*}{-.77} & \multirow{2}{*}{.449} \\
\hline & & post & 30 & 6.80 & 0.93 & & \\
\hline & \multirow{2}{*}{$\begin{array}{c}\text { top } \\
\text {-down }\end{array}$} & pre & 30 & 5.40 & 1.61 & \multirow{2}{*}{-.29} & \multirow{2}{*}{.775} \\
\hline & & post & 30 & 5.60 & 1.14 & & \\
\hline \multirow{4}{*}{ Com-pared } & \multirow{2}{*}{$\begin{array}{l}\text { bottom- } \\
\text { up }\end{array}$} & pre & 30 & 7.10 & 1.16 & \multirow{2}{*}{-.35} & \multirow{2}{*}{.729} \\
\hline & & post & 30 & 7.30 & 1.13 & & \\
\hline & \multirow{2}{*}{$\begin{array}{c}\text { top } \\
\text {-down }\end{array}$} & pre & 30 & 5.10 & 1.88 & \multirow{2}{*}{-.60} & \multirow{2}{*}{.552} \\
\hline & & post & 30 & 5.60 & 1.43 & & \\
\hline \multirow{4}{*}{$\begin{array}{l}\text { Experimen- } \\
\text { tal }\end{array}$} & \multirow{2}{*}{$\begin{array}{l}\text { bottom- } \\
\text { up }\end{array}$} & pre & 30 & 5.70 & 1.21 & \multirow{2}{*}{$\begin{array}{c}- \\
3.13\end{array}$} & \multirow{2}{*}{.006} \\
\hline & & post & 30 & 7.40 & 0.97 & & \\
\hline & \multirow{2}{*}{$\begin{array}{c}\text { top } \\
\text {-down }\end{array}$} & pre & 30 & 5.90 & 1.73 & \multirow{2}{*}{-.71} & \multirow{2}{*}{.484} \\
\hline & & post & 30 & 6.50 & 0.67 & & \\
\hline
\end{tabular}

There was no significant difference for the controlled group in both the bottom-up $(\mathrm{p}=.449)$ and top-down $(\mathrm{p}=.775)$ questions. The comparison group showed no difference in both the bottom-up $(\mathrm{p}=.729)$ and top-down $(\mathrm{p}=.552)$ questions. However, the experimental group showed a significant difference in the bottom-up test $(\mathrm{p}=.006)$. It can be inferred that the vocabulary link repetition and self-diagnosis function from the Smartree Reading Program were useful in bottom-up types such as sentence completion which requires repetition and practice.

4.1.2 Reading Ability by Learner Level: The improvement in reading ability of higher and lower level groups in the controlled, comparison and experimental groups was compared by conducting a post- test. The results are as follows. See Table 5. In the case of the controlled group, there was no significant difference in reading ability improvement for both higher and lower level groups. In the case of the comparison group, the higher-level groups showed no difference in improvement $(\mathrm{p}=.014)$ while lower-level groups showed significant differences $(p=.014)$.

Table 5. Results of Reading Ability by Learner Level

\begin{tabular}{|c|c|c|c|c|c|c|c|}
\hline group & level & test & $\mathrm{N}$ & Mean & SD & $t$ & $p$ \\
\hline \multirow{4}{*}{$\begin{array}{l}\text { Con- } \\
\text { trolled }\end{array}$} & \multirow{2}{*}{ high } & pre & 15 & 13.4 & 2.07 & \multirow{2}{*}{-.16} & \multirow{2}{*}{.879} \\
\hline & & post & 15 & 13.6 & 2.94 & & \\
\hline & \multirow{2}{*}{ low } & pre & 15 & 10.2 & 1.64 & \multirow{2}{*}{-1.21} & \multirow{2}{*}{.260} \\
\hline & & post & 15 & 11.2 & 0.83 & & \\
\hline \multirow{4}{*}{$\begin{array}{l}\text { Com- } \\
\text { pared }\end{array}$} & \multirow{2}{*}{ high } & pre & 15 & 14.0 & 2.23 & \multirow{2}{*}{-.14} & \multirow{2}{*}{.889} \\
\hline & & post & 15 & 14.2 & 2.16 & & \\
\hline & \multirow{2}{*}{ low } & pre & 15 & 10.4 & 0.89 & \multirow{2}{*}{-3.13} & \multirow{2}{*}{.014} \\
\hline & & post & 15 & 11.8 & 0.44 & & \\
\hline
\end{tabular}




\begin{tabular}{lccccccc}
\hline \hline & high & pre & 15 & 13.6 & 0.98 & & \\
\cline { 2 - 6 } Experi- & & post & 15 & 15.0 & 1.41 & & \\
\cline { 2 - 7 } mental & low & pre & 15 & 9.6 & 1.51 & \multirow{2}{*}{-3.05} & \multirow{2}{*}{016} \\
\cline { 2 - 7 } & & post & 15 & 12.8 & 1.78 & & \\
\hline
\end{tabular}

There was no significant difference for higher-level students in the experimental group, but the lower-level group showed a significant difference $(\mathrm{p}=.016)$. It can be said that the Smartree reading program was beneficial for lower-level learners who had difficulties, by helping them search for vocabulary and background knowledge. This result suggests that using the Smartree reading program for low level students had a significant effect in performing bottom up reading tasks.

\subsection{The Effects of SRPI on Affective Attitude}

For finding out change sin students' affective attitude in studying English and reading, the researcher performed a preand post- test. The results are as follows. See Table 6 .

Table 6. Results of Affective Attitude by Groups

\begin{tabular}{cccccccc}
\hline \hline \multirow{2}{*}{ group } & \multirow{2}{*}{$\mathrm{N}$} & \multicolumn{2}{c}{ Pre score } & \multicolumn{2}{c}{ Post score } & \multirow{2}{*}{$t$} & $p$ \\
\cline { 3 - 6 } & & Mean & $\mathrm{SD}$ & Mean & $\mathrm{SD}$ & & \\
\hline $\begin{array}{c}\text { Con- } \\
\text { trolled }\end{array}$ & 30 & 3.67 & .632 & 3.74 & .501 & -.29 & .777 \\
\hline $\begin{array}{c}\text { Com- } \\
\text { pared }\end{array}$ & 30 & 3.64 & .653 & 3.98 & .306 & -1.49 & .153 \\
\hline $\begin{array}{c}\text { Experi- } \\
\text { mental }\end{array}$ & 30 & 3.55 & .622 & 4.38 & .234 & -3.93 & .001 \\
\hline
\end{tabular}

There were no significant changes in affective attitude of the controlled and comparison groups. The comparison group showed some improvement in affective attitude but it was not statistically significance. The experimental group showed significant improvement of affective attitude $(p=.001)$. These results show that using the Smartree program for reading had positive effects in changing student's affective attitude.

4.2.1 Affective Attitude by Survey Type: For finding out more detailed results, pre- and post-surveys (5 survey questions for attitude and motivation, 5 survey questions for studying English and 5 survey questions for English reading attitude) were administered. The results are as follows. See Table 7.

Table 7. Results of Affective Attitude by Survey Type

\begin{tabular}{|c|c|c|c|c|c|c|c|}
\hline group & type & test & $\mathrm{N}$ & Mean & SD & $t$ & $p$ \\
\hline \multirow{6}{*}{ Con-trolled } & \multirow{2}{*}{$\begin{array}{l}\text { moti- } \\
\text { vation }\end{array}$} & pre & 30 & 3.50 & 0.68 & \multirow{2}{*}{-.86} & \multirow{2}{*}{.404} \\
\hline & & post & 30 & 3.72 & 0.44 & & \\
\hline & \multirow{2}{*}{$\begin{array}{c}\text { learni- } \\
\text { ng }\end{array}$} & pre & 30 & 3.88 & 0.57 & \multirow{2}{*}{-.09} & \multirow{2}{*}{.929} \\
\hline & & post & 30 & 3.90 & 0.41 & & \\
\hline & \multirow{2}{*}{$\begin{array}{c}\text { attitu- } \\
\text { de }\end{array}$} & pre & 30 & 3.64 & 0.74 & \multirow{2}{*}{-.06} & \multirow{2}{*}{.953} \\
\hline & & post & 30 & 3.62 & 0.76 & & \\
\hline Com-pared & moti- & pre & 30 & 3.66 & 0.68 & - & .090 \\
\hline
\end{tabular}

\begin{tabular}{|c|c|c|c|c|c|c|c|}
\hline & vation & post & 30 & 4.06 & 0.19 & 1.80 & \\
\hline & \multirow{2}{*}{$\begin{array}{l}\text { learni- } \\
\text { ng }\end{array}$} & pre & 30 & 3.78 & 0.50 & \multirow{2}{*}{$\begin{array}{c}- \\
1.56\end{array}$} & \multirow{2}{*}{.136} \\
\hline & & post & 30 & 4.08 & 0.34 & & \\
\hline & \multirow{2}{*}{$\begin{array}{c}\text { attitu- } \\
\text { de }\end{array}$} & pre & 30 & 3.50 & 0.81 & \multirow{2}{*}{$\begin{array}{c}- \\
1.03\end{array}$} & \multirow{2}{*}{.315} \\
\hline & & post & 30 & 3.82 & 0.55 & & \\
\hline \multirow{6}{*}{$\begin{array}{l}\text { Experimen- } \\
\text { tal }\end{array}$} & \multirow{2}{*}{$\begin{array}{l}\text { moti- } \\
\text { vation }\end{array}$} & pre & 30 & 3.56 & 0.48 & \multirow{2}{*}{5.} & \multirow{2}{*}{.000} \\
\hline & & post & 30 & 4.48 & 0.29 & & \\
\hline & \multirow{2}{*}{$\begin{array}{l}\text { learni- } \\
\text { ng }\end{array}$} & pre & 30 & 3.60 & 0.65 & \multirow{2}{*}{3.44} & \multirow{2}{*}{.003} \\
\hline & & post & 30 & 4.36 & 0.25 & & \\
\hline & \multirow{2}{*}{$\begin{array}{l}\text { attitu- } \\
\text { de }\end{array}$} & pre & 30 & 3.52 & 0.78 & \multirow{2}{*}{$\begin{array}{c}- \\
3.03\end{array}$} & \multirow{2}{*}{.007} \\
\hline & & post & 30 & 4.32 & 0.30 & & \\
\hline
\end{tabular}

According to the results, there were no significant changes in the controlled and comparison groups. However, the experimental group showed significant changes in motivation, studying English and attitude toward reading. There was a noticeable change in general motivation for English $(\mathrm{p}=.000)$.

4.2.2 Affective Attitude by Learner Level: For finding out differences between the lower and higher level groups, significance verification for attitude improvement of group levels was performed. The results are as follows. See Table 8 .

Table 8. Results of Affective Attitude by Learner Level

\begin{tabular}{|c|c|c|c|c|c|c|c|}
\hline group & level & test & $\mathrm{N}$ & Mean & SD & $t$ & $p$ \\
\hline \multirow{4}{*}{$\begin{array}{l}\text { Con } \\
\text { troled }\end{array}$} & \multirow{2}{*}{ high } & pre & 15 & 4.25 & 0.20 & \multirow{2}{*}{0.43} & \multirow{2}{*}{.678} \\
\hline & & post & 15 & 4.21 & 0.03 & & \\
\hline & \multirow{2}{*}{ low } & pre & 15 & 3.09 & 0.14 & \multirow{2}{*}{-2.10} & \multirow{2}{*}{.069} \\
\hline & & post & 15 & 3.28 & 0.14 & & \\
\hline \multirow{4}{*}{$\begin{array}{l}\text { Com- } \\
\text { pared }\end{array}$} & \multirow{2}{*}{ high } & pre & 15 & 4.25 & 0.07 & \multirow{2}{*}{0.86} & \multirow{2}{*}{.413} \\
\hline & & post & 15 & 4.10 & 0.37 & & \\
\hline & \multirow{2}{*}{ low } & pre & 15 & 3.03 & 0.19 & \multirow{2}{*}{-6.84} & \multirow{2}{*}{.000} \\
\hline & & post & 15 & 3.86 & 0.20 & & \\
\hline \multirow{4}{*}{$\begin{array}{l}\text { Experi- } \\
\text { mental }\end{array}$} & \multirow{2}{*}{ high } & pre & 15 & 4.14 & 0.06 & \multirow{2}{*}{-1.70} & \multirow{2}{*}{.128} \\
\hline & & post & 15 & 4.37 & 0.29 & & \\
\hline & \multirow{2}{*}{ low } & pre & 15 & 2.97 & 0.09 & \multirow{2}{*}{-15.0} & \multirow{2}{*}{.000} \\
\hline & & post & 15 & 4.40 & 0.19 & & \\
\hline
\end{tabular}

There were no significant changes in the high and low level students of the controlled and comparison groups but there was significant change in the lower level students of the comparison group. Also, higher level students showed no significant changes, while lower levels in the compared and experimental groups exhibited adequately significant change $(\mathrm{p}=.000)$.

As the research results above indicate, there was a significant change in affective attitude for students in the Smartree reading program groups. Also, lower level learners using the PDF e-book showed a positive effect and lower level learners in the controlled group using the traditional book showed a significant change in some aspects. During the research, the expectations of the new type of English reading 
class were analyzed. Lower level learners, participated actively and responded positively. The participants in this research were willing to use the Smartree reading program, and the e-book users asked whether they could use the Smartree reading program assisted functions on PDF e-book. The control group using traditional books wanted to learn through the Smartree reading program instruction.

\subsection{The Satisfaction Survey Results of SRPI}

The English reading ability test and the survey of affective attitude were followed by the survey of learners' satisfaction for the system and content of the research. Learners' satisfaction focused on the Smartree reading program and PDF e-book, convenience in use, and satisfaction of subject content. The survey used a 5 point scale and consisted of 20 questions. The higher the scores were, the higher the satisfaction was. This survey guaranteed validity such as system satisfaction $(\alpha=.901)$, education satisfaction $(\alpha=.900)$ and overall program satisfaction $(\alpha=.951)$. The results are as follows. See Table 9 .

Table 9. Satisfaction Survey Results of SRPI

\begin{tabular}{|c|c|c|c|c|c|}
\hline group & $\mathrm{N}$ & Mean & SD & $F$ & $p$ \\
\hline compared & 30 & 66.90 & 4.121 & \multirow{2}{*}{-12.128} & \multirow{2}{*}{.000} \\
\hline experimental & 30 & 89.30 & 3.137 & & \\
\hline
\end{tabular}

Each question was worth 5 points and the highest possible score was 100. The score of the comparison group was 66.90 and the score of the experimental group was 89.30. The difference was 22.90 and p-value was .000 , which means it was statistically very significant.

\subsection{Teachers' Note \& Learners' Diary}

4.4.1 Teachers' Note: The teacher's notes about lessons using the Smartree program were written after each lesson was finished. The teacher's notes included preparation for class, what to teach, how to teach, responses from students, and feedback for future lessons. The summary of these notes is as follows.

The reading lesson using reading materials in the Smartree program was strange to both teachers and students. Therefore, teachers needed preparation. At first, there were distractions in the classroom, with lots of students asking questions, but the students who learned how to use it became independent and self-reliant.

In addition, even though there was not a lot of the amount of learning in the beginning, there were many students who came late to have their workbooks checked, so teachers were busy checking them before leaving the classroom. Many students didn't understand the content of the workbooks well so they got the wrong answers. After that, the time students were checked didn't delay in spite of increasing the amount of learning and the number of wrong answers submitted by students decreased, which may indicate that reading speed using reading data in the Smartree program increased accuracy in problem-solving.
4.4.2 Learners' Diary: The learners wrote their diaries after each lesson to write down their opinions and attitudes on the lessons using the Smartree program. In total, 8 diary entries from each learner were collected. Their opinions and attitudes shown in their diaries were analyzed qualitatively focusing on two aspects: practical materials for class and developing class. The summary of the diary entries is as follows.

The class utilizing the Smartree reading program had to adjust to the new method of teaching. Furthermore, there were students who rejected English learning in the time a regular English class was not by their homeroom teachers. At the beginning of the eight classes using the Smartree reading program, students were unfamiliar with the lessons and were confused, saying they didn't know where to look in order to find the data. When students found the vocabulary they didn't know, they tried to search for it using the internet dictionary. As students became used to looking for data, they showed an interest in using the new Smartree reading program each week, and students who showed the attitude of monitoring the overall content and identifying the meaning of words increased.

When the reading class utilizing Smartree reading program was introduced, there was a thorough explanation of how to use the program, but students were still unsure of what they had to do. As the weeks went on, students became competitive in wanting to have their workbooks checked and obtain free time after studying learning patterns. Also, it was found that teachers should let students check each others' answers by dividing students into two groups focusing on some excellent students rather than checking students' answers one by one. This will be necessary so that students who are excessively low level learners may not feel singled out.

\section{CONCLUSION}

This study investigated the effect of how using a tablet PC based Smartree reading program affects English reading ability and affective attitude, and the satisfaction levels of teachers and learners using the program. The conclusions are as follows:

First, the use of a tablet PC based Smartree reading program is more effective in bottom-up reading, so if vocabulary and expressions learning programs are made easy to use and available to students, it is expected that it will greatly improve the reading ability of students. Second, the use of a tablet PC based Smartree reading program was more effective for lower level students, so if it is used to improve learning motivation and self-direction of low level students, it is expected to have positive effects.

The conclusions on the affective attitude for the learning of English reading using the Smartree reading program are as follows: First, the use of the Smartree reading program is positive for the overall improvement of affective attitude especially for reading and attitude of learners. If this program is implemented in schools, it is expected that there will be a positive change in affective attitude. Second, the use of the Smartree reading program is mostly helpful for the affective attitude of lower level students and it can be used as a good tool in increasing their self-direction and motivation. 
The conclusions on the satisfaction levels of the Smartree reading program are as follows. First, the related programs should supply a stable system minimizing errors in the future. Second, they should increase the learner's self-direction supplying user centered interface (interaction, self-review, etc.) using advantages of the system. Third, they should supply various related learning materials that can increase learning effects for the improvement of educational satisfaction and interface that the repeat learning is possible.

The research results show that the use of a tablet PC based Smartree reading program has meaningful effects both for the bottom-up reading task solving ability and reading ability of lower level students, and for bringing about changes in affective attitude.

\section{REFERENCES}

[1] B. G. Lee, K. C. Park, S. J. Kim, and E. S. Jeong, "Empirical Analysis of Learning Effectiveness in uLearning Environment with Digital Textbook," KSII Transactions of Internet and Information Systems, vol. 6, no. 3, Sep. 2012, pp. 869-885.

[2] M. S. Kim, A Study on the Effects of English Reading Skill on Listening and Speaking Ability for the English Beginners in Elementary Schools, master's dissertation, Busan National University of Education, 2000.

[3] J. R. Kim and J. Y. Hwang, "A Study of Running English Extra-curricular Classes in An Elementary School Using Extensive Reading Program," English Education Research, vol. 18, no. 2, July. 2006, pp. 243-270.

[4] D. Howard, Cognitive psychology, Macmillan, New York, 1985.

[5] J. Richards, "Listening Comprehension: Approach, Design, Procedure," TESOL Quarterly, vol. 17, no. 2, Jun. 1983, pp. 219-240.

[6] E. Sapir, Language: An Introduction to the Study of Speech, Harcourt Brace, New York, 1921.

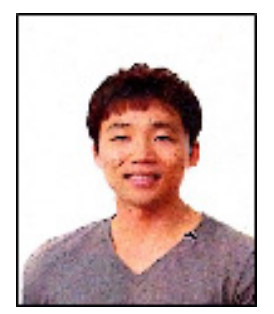

Myeong Gi Jeong

$\mathrm{He}$ received the B.S. in elementary education from Seoul National University of Education, Korea in 2002 and also received an M.S. in elementary English education from Korea National University of Education, Korea in 2012. Since 2004, he has been working at Seoul Song Jeong Elementary School as a teacher. His main research interests include Smart English learning and English learning for underachievers.

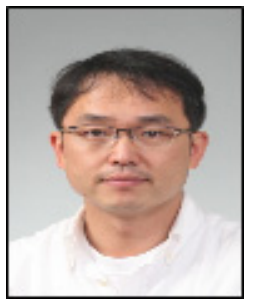

Hee Cheol Jeon

$\mathrm{He}$ received the B.S. in elementary education from Kyeongin National University of Education, Korea in 1997 and also received an M.S., and Ph. D. in elementary English education from Korea National University of Education, Korea in 2008 and 2013 respectively. Since 1997, he has been working in elementary schools in the Kyeonggi area as a teacher. His main research interests include vocabulary learning and Smart English learning.

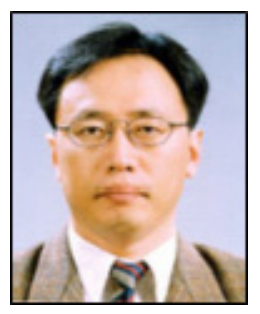

\section{Jeong Ryeol Kim}

$\mathrm{He}$ has a Ph.D. in applied linguistics from the University of Hawaii and is a professor of English at Korea National University of Education (KNUE) teaching methodology, integrated content language teaching, and English linguistics. He is currently serving as the president of Korea Association of Foreign Languages Education for 2013-2014 and was the president of Korea Association of Primary English Education for 2010-2011 and the president of KOTESOL back in 1996-1997. He was involved in different government projects in curriculum, textbooks and English education using information and communications technology. He has published numerous articles and books in the area of elementary English education and technology enhanced English teaching 